\title{
Faktor-Faktor Internal PenentuPertumbuhan Perusahaan Pertambangan Yang Terdaftar Di Bursa Efek Indonesia Tahun 2010-2014
}

\author{
${ }^{1}$ Eveline \\ ${ }^{2}$ Ishak Ramli \\ ${ }^{1}$ Fakultas Ekonomi, Universitas Kristen Krida Wacana, Jakarta \\ ${ }^{2}$ Fakultas Ekonomi, Universitas Tarumanagara, Jakarta
}

ABSTRAK

Harga saham industri pertambangan pada Bursa Efek Indonesia (BEI) mengalami penurunan drastis sejak tahun 2010, sementara IHSG mengalami peningkatan. Akademisi sering atau sebagian besarmenjadikan growth dan harga saham sebagai objek penelitiannya, dan hasilnya bahwa growth mempengaruhi harga saham. Penelitian ini bertujuan meneliti faktor-faktor yang mempengaruhi growth dengan sampel 25 perusahaan pertambangan yang terdaftar di Bursa Efek Indonesia. Variabel independen yang digunakan dalam penelitian ini adalah profitabilitas, likuiditas, leverage, dan cash flow. Berdasarkan data sampel perusahaan pertambangan dari tahun 2010-2014 penelitian dibagi menjadi 2 periode, yaitu tahun 2010-2011 dan tahun 2012-2014. Perbedaan ini untuk mengantisipasi perubahan standard akuntansi keuangan yang mewajibkan perusahaan emiten menggunakan PSAK konfergensi IFRS sejak 2012. Analisis data menggunakan analisis regresi berganda guna menguji hipotesis faktor-faktor penentu growth: profitabilitas, arus kas, leverage, dan likuiditas terhadap growth pendapatan maupun keuntungan. Hasilnya bahwa pertumbuhan pendapatan dan keuntungan 96\%-98\% ditentukan oleh profitabilitas, arus kas, leverage dan likuiditas sebelum tahun 2012, namun setelah tahun 2012, profitabilitas, arus kas, leverage dan likuiditas sebagai penentu 32\% pertumbuhan pendapatan dan $70 \%$ pertumbuhan keuntungan. Profitabilitas positif signifikan mempengaruhi pertumbuhan. Arus Kas signifikan positif mempengaruhi pertumbuhan (growth). Sementara leverage dan likuiditas cenderung negatif mempengaruhi growth. Kemudian, arus kas sangat mempengaruhi pertumbuhan keuntungan tetapi tidak demikian hal nya untuk pertumbuhan pendapatan. Pertumbuhan industri pertambangan di BEI banyak ditentukan oleh arus kas, sementara pertumbuhan berbanding terbalik dengan penggunaan utang.

Kata kunci: growth, penentu growthleverage, arus kas

\section{PENDAHULUAN}

Industri pertambangan pada pasar modal di Indonesia menjadi sorotan. Berdasarkan informasi dari media Kompas yang terbit pada 5 Mei 2015, BPS mencatat untuk periode kuartal 1 di tahun 2015, industri pertambangan sedang mengalami masa sulit dengan penurunan Indeks Tendensi Bisnis terendah sebesar 87,16.Padahal pada tahun-tahun sebelumnya, industri pertambangan menjadi andalan negara. Selain memberikan kontribusi pendapatan negara, industri pertambangan juga menyediakan lapangan kerja bagi masyarakat Indonesia. Namun hari ini, industri pertambangan mengalami kondisi terpuruk. Harga saham sektor pertambangan mengalami penurunan tajam.

Beberapa faktor yang mempengaruhi harga saham pada literatur, yaitu pajak, profitability, liquidity, liability, growth, dan sebagainya. Growth secara simultan dengan variabel lain dan secara parsial memiliki hubungan positif terhadap harga saham (Rowland Bismark Fernando Pasaribu, 2008). Bahkan growth sendiri memiliki pengaruh terhadap harga saham di berbagai sektor industri pada bursa efek. Sebaliknya harga saham dan growth memiliki hubungan positif yang kuat.

Literatur mencatat faktor-faktor yang dapat mempengaruhi growth, yaitu ukuran dan umur perusahaan, profit, produktifitas, dan inovasi yang dilakukan perusahaan (Alex Coad dan Werner Holzi, 2010).Dalam Gibrat Law (Robert Gibrat, 1931), tingkat proporsional pertumbuhan suatu perusahaan tidak tergantung dari ukuran perusahaan tersebut. Ukuran perusahaan tidak selalu mempengaruhi growth. Namun Gibrat Law ini dibantah oleh beberapa penelitian(Coad, 2009), menghasilkan bahwa ada hubungan negatif antara growth dengan ukuran perusahaan. Artinya perusahaan yang lebih kecil dan lebih muda, memiliki tingkat pertumbuhan growth lebih tinggi daripada perusahaan yang lebih tua dan lebih besar. Umur perusahaan juga mempengaruhi perusahaan. Evans (1987), menyimpulkan bahwa perusahaan yang sudah tua memiliki pertumbuhan growth yang lebih lambat dibandingkan perusahaan baru.

Faktor penentu growthlainnya yaitu ukuran perusahaan, inovasi perusahaan, dan share ekspor perusahaan (Antje Schimke dan Thomas Brenner, 2011). Ketika inovasi memiliki dampak yang terbatas pada pertumbuhan penjualan, itu jauh lebih penting bagi perusahaan dengan pertumbuhan tercepat (Coad 
dan Rao, 2008; Stam dan Wennberg, 2009). Karakteristik hubungan antara inovasi dan growth konsisten dengan karakteristik inovasi sebagai aktifitas yang tidak pasti. Inovasi sendiri dapat diukur dengan melihat biaya Research \& Development (R\&D), jumlah paten yang dimiliki perusahaan, atau dengan kuisioner terkait inovasi perusahaan yang dilakukan oleh lembaga survey.

Perusahaan kecil dan baru berdiri, memiliki tingkat liquidity yang lebih tinggi dibandingkan perusahaan besar dan sudah lama berdiri. sehingga growth perusahaan kecil dan baru berdiri lebih besar daripada perusahaan besar dan sudah lama berdiri (Blandina Oliveira dan Adelino Fortunato, 2005).. Cash flow meningkatkan growth penjualan (Thomas H. Brush, Philip Bromiley, dan Margaretha Hendrickx, 2013). Korelasi growth dan cash flow dalam dunia perbankanlebih besar dari pada cash flow ke growth(Drew Dahl, 2012).

Faktor-faktor sumber daya pengelola perusahaan misalnya pendidikan, umur, motivasi, dan sebagainya, perusahaan itu sendiri seperti umur perusahaan, sektor bisnis, lokasi, dan sebagainya, serta strategi meliputi pelatihan manajemen, kompetisi, ekspor, saham, dan sebagainya mempengaruhi growth perusahaan (Mercedes Teruel Carrizosa, 2007). Faktor lainnya yang mempengaruhi growth yaitu performa struktur modal perusahaan, sumber dana internal dan eksternal, saham, external debt dan cash flow(Mercedes Teruel dan Agusti Segarra, 2009).

Skala ekonomi dan disekonomi, merger dan akuisisi, kebijakan pemerintah, penentu struktur pasar, profit merupakan faktor-faktor yang mempengaruhi growth. Selain itu, produktifitas juga mempengaruhi growth (Aghion et al, 2008,Sebenarnya produktifitas dan profit adalah 2 variabel yang sangat erat hubungannya. Maka pada beberapa penelitian, mencatat bahwa hubungan antara produktifitas dengan growth sama seperti hubungan profit dengan growth. Signifikan namun pengaruhnya tidak terlalu besar. Namun ada juga penelitian yang membantah teori ini. Aghion et al (2008) menyatakan bahwa produktifitas dan growth memiliki hubungan yang sangat positif

Perusahaan yang memiliki profit besar, akan tumbuh lebih besar daripada perusahaan yang memiliki profit kurang (atau tidak memiliki profit). Sebenarnya, perusahaan yang memiliki profit tidak selalu berarti akan melakukan ekspansi keuangan, kecuali mempunyai motivasi untuk tumbuh serta perekonomian juga sedang bertumbuh. Secara statistik, hubungan antara growth dan profit memang signifikan. Namun, Coad (2007) menghasilkan bukti bahwa growth lebih berpengaruh positif terhadap profit, daripada profit terhadap growth. Hubungan kausal juga terjadi antara pertumbuhan ekonomi, harga minyak, kedalaman pasar saham, dan tiga variabel ekonomi makro lainnya (nilai tukar, inflasi, dan suku bunga) serta dalam jangka panjang, ada aliran kausal searah variabel makroekonomi dengan pertumbuhan ekonomi. (Rudra P. Pradhan, Mak B. Arvin, dan Atanu Ghoshray, 2015). Dalam jangka pendek, mereka menemukan hubungan kompleks antara variabel-variabel.

Variabel makro ekonomi juga mempengaruhi performa perusahaan dalam meningkatkan growth.Profit (return on assets), leverage(debt to equity ratio) Return on Equity (ROE),Net Profit Margin (NPM), dan Current ratio secara bersama-sama mempengaruhi growth pada perusahaan manufaktur (Rasyid, 2008, Mohd. Heikal, Muammar Khaddafi, dan Ainatul Ummah, 2014), Secara parsial, ROA, ROE, dan NPM siginifikan dan positif mempengaruhi growth. Sedangkan DER dan Current rationegatif mempengaruhi growth.

Studi ini bertujuan membuktikan dan mengkaji mengapa profitability,liquidity, leveragecash flow, mempengaruhigrowthpada perusahaan pertambangan yang terdaftar di Bursa Efek Indonesia?

\section{METODE PENELITIAN}

Penelitian dilakukan pada perusahaan pertambangan yang terdaftar di Bursa Efek Indonesia dengan rentang periode 2010 hingga 2014. Data diambil dari website resmi Bursa Efek Indonesia, yaitu www.idx.co.id. Data diperoleh dari laporan keuangan perusahaan-perusahaan yang menjadi cakupan penelitian ini, yang diambil dari website Bursa Efek Indonesia selama periode 2010 hingga 2014. Metode verifikatifdigunakan untuk melakukan pengujian hipotesis dan mencari bukti empiris pengaruh profitability, liquidity, leverage, cash flowterhadap growth.

\section{Unit Analisis}


Sampel penelitian 25perusahaan terbuka yang bergerak di sektor pertambangan Indonesia yang terdaftar di Bursa Efek Indonesia, dari populasi yang berjumlah 40 perusahaan.Filterisasi dilakukan karena adanya perusahaan yang baru masuk ke Bursa Efek Indonesia di atas tahun 2010, kemudian ada pula perusahaan yang saat ini sudah tidak aktif lagi.

\section{Operasionalisasi variabel}

Tabel 2 Operasionalisasi Variabel

\begin{tabular}{|c|c|c|c|}
\hline Dimensi & Indikator & Keterangan & Sumber \\
\hline $\begin{array}{l}\text { GrowthSal } \\
\text { es }\end{array}$ & $\frac{\operatorname{growthsales}(t)-\text { growthsales }(t-1)}{\text { growthsales }(t-1)} \times 100 \%$ & $\begin{array}{l}\text { Variabel } \\
\text { Dependen }\end{array}$ & $\begin{array}{l}\text { Blandina } \\
\text { Oliveira \& } \\
\text { Adelino } \\
\text { Fortunato } \\
\text { (2005) }\end{array}$ \\
\hline $\begin{array}{l}\text { GrowthEar } \\
\text { ning }\end{array}$ & $\frac{\text { growthearning }(t)-\text { growthearning }(t-1)}{\text { growthearning }(t-1)} \times 100 \%$ & $\begin{array}{l}\text { Variabel } \\
\text { Dependen }\end{array}$ & $\begin{array}{l}\text { Schleicher, et } \\
\text { al(2010) }\end{array}$ \\
\hline $\begin{array}{l}\text { NetProfitM } \\
\text { argin }\end{array}$ & $\frac{N P M(t)-N P M(t-1)}{N P M(t-1)} \times 100 \%$ & $\begin{array}{l}\text { Variabel } \\
\text { Independen }\end{array}$ & $\begin{array}{l}\text { Gennady } \\
\text { Bilych (2012) }\end{array}$ \\
\hline $\begin{array}{l}\text { Current } \\
\text { ratio }\end{array}$ & $\frac{\text { currentratio }(t)-\text { currenratio }(t-1)}{\text { currentratio }(t-1)} \times 100 \%$ & $\begin{array}{l}\text { Variabel } \\
\text { Independen }\end{array}$ & $\begin{array}{l}\text { Blandina } \\
\text { Oliveira } \quad \& \\
\text { Adelino } \\
\text { Fortunato } \\
(2005)\end{array}$ \\
\hline $\begin{array}{l}\text { Debt } \quad \text { to } \\
\text { equity ratio }\end{array}$ & $\frac{D E R(t)-D E R(t-1)}{D E R(t-1)} \times 100 \%$ & $\begin{array}{l}\text { Variabel } \\
\text { Independen }\end{array}$ & $\begin{array}{l}\text { Bill Francis } \\
(2011)\end{array}$ \\
\hline Cash flow & $\begin{array}{l}\text { Revenue - COGS - Operating Expense - Interest - Tax - Dividen Preferred } \\
\text { Stock + Depresiasi/Amortisasi - Working Capital Requirement - Fixed Assets } \\
\text { Used }\end{array}$ & $\begin{array}{l}\text { Variabel } \\
\text { Independen }\end{array}$ & $\begin{array}{l}\text { Miguel \& } \\
\text { Maria (2002) }\end{array}$ \\
\hline
\end{tabular}

*Keterangan: $\mathrm{t}$ adalah tahun saat ini; $\mathrm{t}-1$ adalah tahun sebelumnya

\section{Teknik Analisis Data}

Analisis data menggunakan analisis regresi berganda guna menguji hipotesis pengaruh masingmasing variabel, yaitu profitability, liquidity, leverage, dan cash flowterhadap growth.

Berikutmodel penelitian:

Keterangan:

$$
\text { Growth }=\beta_{0}+\beta_{1} \text { Prof }+\beta_{2} \text { Liq }+\beta_{3} \text { Lev }+\beta_{4} C F+\varepsilon
$$

$$
\begin{aligned}
& \text { Prof = Profitability } \\
& \text { Liq = Liquidity } \\
& \text { Lev = Leverage } \\
& \text { CF = Cash flow } \\
& \varepsilon=\text { error }
\end{aligned}
$$

- Pengujian Keberartian Model Regresi

Sedangkan pengujian simultan digunakan untuk menguji dengan menggunakan uji F. Model cocok jika $F$ Change $<\alpha=0.05$ dan sebaliknya bila $\alpha>0,05$

\section{HASIL DAN PEMBAHASAN Hasil Penelitian}

Data diolah dengan menggunakan pemrograman statistik EViews versi 9. Data diolah menjadi 2 bagian. Yaitu data periode tahun 2010-2011 dan data periode tahun 2012-2014. Hal ini dilakukan karena per tahun 2012, semua perusahaan membuat laporan keuangan dengan menggunakan PSAK konvergensiInternational Financial Reporting Standards (IFRS.)

\section{a. Analisis Regresi}


Dari hasil uji heteroskedastisitas, uji Chow, dan uji Chi untuk masing-masing data 2010-2011 dan data 2012-2014, dapat dirumuskan pengolahan data yang akan dilakukan pada pedoman dalam melakukan analisis regresi.

Dari analisis regresi yang telah dilakukan, maka di dapat empat model penelitian sebagai berikut.

1. Data periode tahun 2010-2011

Growth (Profit) $=5,65+0,785$ Cash flow - 0,020 Current ratio - 0,076 DER + 0,166 NPM

Growth $($ Revenue $)=1,727-0,004$ Cash flow - 0,003 Current ratio - 0,011 DER - 0,002 NPM

2. Data periode tahun 2012-2014

- Growth (Profit) $=-0,224+0,084$ Cash flow -0,0003 Current ratio - 0,006 DER + 0,009 NPM

- Growth (Revenue) =0,0997 + 0,001 Cash flow - 0,0004 Current ratio + 0,005 DER + 0,004 NPM

Tabel 3 dan Tabel 4. merupakan hasil analisis regresi untuk data tahun 2010-2011, sedangkan Tabel 5 dan Tabel 6 merupakah hasil analisis regresi untuk data tahun 2012-2014.

Tabel 3 Analisis Regresi Data 2010-2011 (Growth profit)

\begin{tabular}{|lcccc|} 
Variabel & Coeficient & Std Error & t- Statistik & Prob. \\
\hline CASH_FLOW & & & & \\
CURRENT_RATIO & 0,784543 & 0,128306 & 6,114620 & 0,0000 \\
DER & $-0,019725$ & 0,000710 & $-27,77480$ & 0,0000 \\
NPM & $-0,076005$ & 0,017865 & $-4,254381$ & 0,0004 \\
C & 0,166432 & 0,022205 & $7,4951000,0000$ & \\
\hline R Squared & 5,650779 & 0,537371 & 10,51560 & 0,0000 \\
\hline Adj R Squared & 0,992515 & & & \\
Prob(F Statistic) & 0,982535 & & & \\
\hline
\end{tabular}

Sumber: data olahan

Analisis regresi untuk data tahun 2010-2011, menggunakan Fixed Effect dan weighted. Adjusted Rsquared dari variabel independen menunjukkan angka $98 \%$.

Cash flow dan profitability (net profit margin) signifikan berpengaruh positif terhadap growth profit. (sesuai dengan hipotesis). Cash flow sendiri memiliki pengaruh yang cukup besar, yaitu 78\%. Jadi apabila cash flow naik 1\%, maka growth profit akan naik $0.78 \%$. Sedangkanliquidity(current ratio) danleverage(debt to equity ratio)signifikan berpengaruh negatif terhadapgrowth profit. Hal ini bertentangan dengan studi literaturMohd. Heikal, Muammar Khaddafi, dan Ainatul Ummah (2014), bahwa current ratio seharusnya berpengaruh positif terhadap growth.

\begin{tabular}{lcccc|} 
Variabel & \multicolumn{2}{c}{ Tabel 4. Analisis Regresi Data 2010-2011 } & (Growth rever \\
Coeficient & Std Error & t- Statistik & Prob. \\
\hline & & & & \\
CASH_FLOW & $-0,004271$ & 0,008227 & $-0,519125$ & 0,6091 \\
CURRENT_RATIO & $-0,002781$ & $0,000131-21,17893$ & 0,0000 & \\
DER & $-0,010924$ & 0,002365 & $-4,619516$ & 0,0001 \\
NPM & $-0,001805$ & 0,011754 & $-0,153527$ & 0,8794 \\
C & 1,727344 & 0,153600 & 11,24573 & 0,0000 \\
\hline R Squared & 0,981291 & & & \\
\hline Adj R Squared & 0,956347 & & & \\
Prob ( F-Statistic) & 0,000000 & & & \\
\hline
\end{tabular}

Sumber: data olahan

Hasil analisis regresi data 2010-2011 dengan variabel dependen growth revenue, tidak jauh berbeda. Nilai adjusted R-squared sangat besar, yaitu 95\%. Semua variabel independen, yaitu cash flow, NPM, DER, dan current ratio memiliki pengaruh negatif terhadap growh revenue, namun yang signifikan mempengaruhi growth.revenue hanya, current ratiodan DER. Sementara Cash flow dan NPM tidak signifikan mempengaruhi negatip growth.revenue 


\begin{tabular}{lcccc}
\hline Variabel & Coeficient & Std Error & t- Statistik & Prob. \\
\hline & & & & \\
CASH_FLOW & 0,084472 & 0,007388 & 11,43323 & 0,0000 \\
CURRENT_RATIO & $-0,000294$ & 0,001054 & $-0,278691$ & 0,7813 \\
DER & $-0,005956$ & 0,015585 & $-0,382159$ & 0,7035 \\
NPM & 0,009389 & 0,003890 & 2,413742 & 0,0184 \\
C & $-0,223990$ & 0,211683 & $-1,058141$ & 0,2936 \\
\hline R Squared & 0,715813 & & & \\
\hline Adj R Squared & 0,699754 & & & \\
Prob(F Statistic) & 0,000000 & & & \\
\hline Sumber: data olahan & & & & \\
\hline
\end{tabular}

Sumber: data olahan

Analisis regresi untuk tahun 2012-2014 berbeda dengan tahun 2010-2011. Dari segi penentuan model juga berbeda. Data tahun 2012-2014 diolah dengan metode Common Pool. Untuk variabel dependen growth profit, Adjusted R-squarednya 69\%. Nilai ini menunjukkan, variabel independen secara bersamasama menjelaskan growth profit sebesar $69 \%$.

Cash flowdanNPM signifikan positifmempengaruhi Growth. Sedangkan DER dan current ratio signifikan negative mempengaruhi Growth. Current ratio, NPM, dan DER memiliki koefisien yang rendah, yaitu di bawah $1 \%$. Sedangkan cash flowmemiliki koefisien $8.4 \%$.

Tabel 6 Analisis Regresi Data 2012-2014 (Growth revenue)

\begin{tabular}{lcccc} 
Variabel & Coeficient & Std Error & t- Statistik & Prob. \\
\hline & & & & \\
CASH_FLOW & 0,001260 & 0,003456 & 0,364647 & 0,7165 \\
CURRENT_RATIO & $-0,000381$ & 0,000207 & $-1,842039$ & 0,0697 \\
DER & 0,004650 & 0,001387 & 3,352521 & 0,0013 \\
NPM & 0,003821 & 0,000730 & 5,237340 & 0,0000 \\
C & 0,099708 & 0,044174 & 2,257191 & 0,0271 \\
\hline R Squared & 0,357201 & & & \\
\hline Adj R Squared & 0,320469 & & & \\
Prob(F Statistic) & 0,000003 & & & \\
\hline
\end{tabular}

Sumber: data olahan

Hasil analisis regresi data periode tahun 2012-2014 dengan variabel dependen growth revenue. Menunjukkan bahwa Adjusted R-squared sebesar 32\%.Current ratio memiliki pengaruh negatif. Sama seperti analisis regresi data periode tahun 2010-2011 dengan variabel dependen growth revenue, hal ini bertentangan dengan studi literatur Mohd. Heikal, Muammar Khaddafi, dan Ainatul Ummah (2014). Kemudian cash flow, DER, dan NPM memiliki pengaruh positif, namun yang signifikan mempengaruhi positip hanya DER dan NPM. Cash flow tidak signifikan positip mempengaruhi Growth Revenue. Current Ratio tidak signifikan mempengaruhi negatip Growth Revenue.Koefisien setiap variabelini di bawah $1 \%$.

\section{Pembahasan}

\section{Profitability}

Profitability signifikan positif mempengaruhi growth revenue, baik pada data periode tahun 20102011 dan data periode tahun 2012-2014, kecuali pada tahun 2010-2011. Sebagian besar model teoritis menyatakan bahwa perusahaan yang memiliki profit besar akan tumbuh, sedangkan perusahaan dengan profit kurang akan menurun (Alex Coad dan Werner Holzi, 2010). Hubungan antara profit dan pertumbuhan tampak jelas, profit menyediakan dana pertumbuhan (Arun Mukhopadhyay dan Sal AmirKhalkhali, 2010).Ketika profit perusahaan meningkat, otomatis perusahaan tersebut mengalami pertumbuhan.Profit yang meningkat menghasilkan tambahan dana/modal yang dapat digunakan untuk aktifitas perusahaan lainnya. Seperti ekspansi, pertambahan produksi, dan sebagainya. Meskipun bagian dari modal untuk ekspansi dapat diperoleh dengan pinjaman, ketersediaan dan biaya pendanaan eksternal umumnya akan lebih rendah bila proporsi yang lebih besar jika menggunakan dana dari internal.

Sedangkan pada tahun 2010-2011, pengaruh profit negatif terhadap growth revenue. Ketika profit di tahun sebelumnya menurun, maka perusahaan akan menjalankan strategi meningkatkan penjualan besarbesaran. Sehingga ada hubungan negatif profit terhadap growth revenue (Johann Dreyer, et al, 2013) 


\section{Liquidity}

Analisis data periode tahun 2010-2011 bahwa likuiditas mempengaruhi growth profit. Semakin likuid suatu perusahaan, berarti ada aset yang lebih besar daripada hutang. Dengan kata lain, aset dapat digunakan oleh perusahaan untuk investasi. Sedangkan untuk growth revenue, liquidity signifikan negative mempengaruhi growth revenue. Hal ini berbeda dengan literatur yang ada. Dari data periode tahun 20122012 baik dengan variabel dependen growth profitmaupaun growth revenue, keduanya tidak berpengaruh signifikan. Liquidity yang tinggi menunjukkan adanya kelebihan uang kas atau aktiva lancar lainnya (Munawir, 2004). Ada kemungkinan liquidity yang besar juga didukung dari piutang yang besar. Sehingga perusahaan memang memiliki kas yang besar, namun fisiknya belum menjadi milik perusahaan. Kas tersebut belum bisa digunakan untuk kebutuhan pertumbuhan profit. Maka semakin besar liquidity, semakin besar pula kesempatan untuk growth yang hilang.

Kemudian liquidity yang rendah juga dapat meningkatkan growth revenue. Liquidity yang rendah bisa dikarenakan liabilitas yang besar dan pinjaman ini digunakan oleh perusahaan untuk meningkatkan produksi dan penjualan. Sehingga pengaruh liquidity menjadi negatif terhadap growth revenue.

liquidity tidak memiliki pengaruh signifikan terhadap growth periode tahun 2012-2014,. Dengan pengaruh negatif, sama seperti data periode tahun 2010-2011. Penerapan laporan keuangan berbasis IFRS aset menggunakan nilai wajar, bukan nilai buku dihitung sejak awal. Banyak faktor yang mempengaruhi harga asetseperti inflasi, kurs, dan suku bunga. (Rudra P. Pradhan, Mak B. Arvin, Atanu Ghosray, 2015; Alberto Petrucci, 1997; Rusmin, Emita W. dan Bambang Hartadi, 2014). Inflasi (tingkat inflasi tinggi), melemahkandaya beli masyarakat. Sehingga produksi perusahaan yang tidak diimbangi daya beli masyarakat dan penjualan akan menurun. Sama seperti kurs, jika kurs negara melemah, harga barang akan naik. Penjualan akan melesu, terutama terhadap barang-barang impor. Jika suku bunga tinggi, masyarakat cenderung menyimpan kas, dan mengurangi jumlah uang yang beredar. Hal ini menyebabkan penjualan kembali menurun, dan sebaliknya (Rudra P. Pradhan, Mak B. Arvin, Atanu Ghosray, 2015)

\section{Leverage}

Leverage signifikan negatif mempengaruhi growth pada data periode tahun 2010-2011, namun tidak signifikan pada data periode tahun 2012-2014 untuk growth profit, dan signifikan positif terhadap growth revenue. Hasil penelitian untuk data tahun 2010-2011, sesuai dengan studi literatur, yaitu leverage mempengaruhi negatif.

Hutang merupakan sumber dana selain modal dan ekuitas. Namun ketika hutang melebihi ekuitas yang dimiliki, risiko liquidity menjadi tinggi. Hal ini berarti perusahaan menggunakan hutang lebih banyak dibandingkan ekuitas di tahun 2011. Hutang tersebut akan menjadi beban dan harus dibayar. Semakin banyak hutang, berarti semakin besar biaya yang harus dibayar. Sehingga pengelola harus bijak dalam menentukan aktiva yang ada. Apakah untuk meningkatkan profit, atau membayar hutang perusahaan. Ketika diputuskan untuk membayar hutang perusahaan, maka pengaruh leverageterhadap growthmenjadi negatif, karena semakin besar DER, semakin kecil peluang untuk meningkatkan growth. Dengan kata lain, kehadiran hutang mencegah investasi berlebihan (Lang, Ofek, Stulz, 1996).

Namun ketika hutang yang dipinjam digunakan untuk kepentingan investasi, maka pengaruh leverageterhadap growthmenjadi positif. Perusahaan akan membandingkan manfaat waktu menunggu sebagai keuntungan. Misal, hutang digunakan untuk investasi dimana investasi tersebut memiliki bunga. Bunga yang akan diperoleh di waktu mendatang, akan di-present value-kan kemudian di pro rata dengan periode sekarang. Sehingga keuntungan akuntansi tersebut sudah dimasukkan sebagai aset (Lyandres dan Zdhanov, 2005). Maka yang membuat leverageberpengaruh positif pada growth revenueselama periode tahun 2012-2014 adalah kemungkinan adanya pemanfaatan hutang untuk peningkatan produksi atau ekspansi pasar sehingga menciptakan kenaikan penjualan.

\section{Cash flow}

Cash flow signifikan mempengaruhi hanya pada growth profit, baik pada data periode tahun 20102011 dan data periode tahun 2012-2014. Keduanya berpengaruh positif. Semakin tinggi cash flow, maka perusahaan mampu mendanai operasional.Ketika perusahaan memiliki kas, perusahaan bisa menjalankan bisnis untuk meningkatkan profit. Perusahaan dengan nilai cash flow yang rendah, pertumbuhannya lebih lambat dibandingkan perusahaan dengan nilai cash flow yang tinggi. Perusahaan akan kesulitan berinvestasi, 
berbeda dengan perusahaan yang nilai cash flownya besar, perusahaan ini mampu mendanai project sendiri (Cabral dan Mata, 2003).

Cash flow juga menggambarkan perputaran kas. Semakin tinggi cash flow, maka semakin cepat kas yang diolah kembali ke perusahaan. Maka profit akan lebih cepat diperoleh (Blandina Oliveira dan Adelino Fortunato, 2005). Namun bagi growth revenue, cash flow tidak signifikan mempengaruhi growth revenue . Hasil analisis regresi ini memang tidak sesuai dengan literatur yang ada, namun Yakov Amihud dan Haim Mendelson (2008) juga menemukan hasil penelitian yang sama. Cash flow lebih tepat digunakan untuk menilai peluang investasi daripada penjualan. Cash flow memang tidak mempengaruhi penjualan, namun penjualan mempengaruhi cash flow. Penjualan akan menjadi cash flow masuk, sehingga jumlah kas yang masuk ini akan mempengaruhi cash flow perusahaan. Namun cash flow perusahaan tidak signifikan mempengaruhi penjualankarenakan penjualan lebih dipengaruhi oleh faktor lain, seperti keadaan pasar.

Dari empat hasil analisis regresi, dapat disimpulkan bahwa ada perbedaan antara data tahun 20102011 dengan data tahun 2012-2014. Kemudian juga ada perbedaan antara data dengan variabel dependen growth profit dan growth revenue. Perbedaan data tahun 2010-2011 dengan tahun 2012-2014, dikarenakan adanya perubahan metode pelaporan keuangan (dari PSAKUS GAAP menjadi PSAK berbasis IFRS). Kemudian perubahan ekonomi sendiri juga menjadi pemicu perbedaan ini. Tahun 2012-2014, growth lebih dipengaruhi oleh ekonomi makro, seperti yang disebutkan pada studi literatur. Beberapa ekonomi makro yang disebut dalam beberapa penelitian adalah inflasi (Rudra P. Pradhan, Mak B. Arvin, Atanu Ghosray, 2015; dan), kemudian kurs atau nilai tukar (Rusmin, Emita W., Bambang Hartadi, 2014; Anthony Flint \& Andrew Tan \& Gary Tian, 2010).

Inflasi, kurs, dan suku bunga lebih mempengaruhi growth revenue. Hal ini dikarenakan inflasi yang tinggi akan menyebabkan daya beli masyarakan melemah (dan sebaliknya), kurs yang melemah akan membuat barang-barang yang dijual menjadi mahal (dan sebaliknya), dan suku bunga yang tinggi menyebabkan masyarakat cenderung menyimpan uang di bank sehingga ekonomi juga melemah (dan sebaliknya). Ini semua akan berdampak pada penurunan penjualan. Sebesar apapun usaha perusahaan untuk mempromosikan produknya, apabila keadaan ekonomi makro tidak mendukung, maka penjualan tidak bisa maksimal.

Selain ekonomi makro, yang mempengaruhi pertumbuhan di tahun 2012-2014 adalah perusahaan itu sendiri. Semakin tahun, persaingan ekonomi antar perusahaan semakin tinggi. Maka, perusahaan juga perlu memperhatikan kualitas internal perusahaan tersebut, yang tidak hanya diukur dari kemampuan operasional perusahaan. Seperti sumber daya manusia yang bekerja di perusahaan tersebut. Tidak dapat dipungkiri, keberhasilan perusahaan ada di tangan SDM yang mengelolanya. Kemudian ada faktor identitas perusahaan itu sendiri, yang mencakup umur perusahaan, sektor perusahaan, dan sebagainya. Perusahaan yang baru berdiri, cenderung belum memiliki banyak hutang. Sehingga dana yang mereka miliki bisa digunakan untuk keperluan investasi (Storey).

Selain itu ada pula inovasi perusahaan, ukuran perusahaan, dan share ekspor (Antje Schimke dan Thomas Brenner, 2011). Inovasi perusahaan dapat dilihat dari aktifitas Research \& Development. Bukan seberapa banyak inovasi yang dihasilkan, namun seberapa besar keberhasilan inovasi yang akan menentukan growthperusahaan. Ukuran perusahaan dilihat dari cakupan perusahaan tersebut. Perusahaan kecil belum mampu menghasilkan revenue sebesar perusahaan besar. Hal ini bisa dikarenakan produktifitas yang belum sebesar produktifitas perusahaan besar, atau dikarenakan masyarakat cenderung memilih produk dari perusahaan besar yang sudah dikenal luas (Antje Schimke dan Thomas Brenner, 2011).Hal seperti ini yang sering luput dari pengamatan, namun ternyata juga mempengaruhi growth.

\section{DAFTAR PUSTAKA}

Adam, Pasrun. 2015. A Model of the Dynamic of the Relationship between Stock Prices and Economic Growth of Indonesia. Applied Economics and Finance 2 (3), 12-19

Aghion, Philippe, Robin Burgess, Stephen J. Redding, and Fabrizio Zilibott.2008. The Unequal Effects of Liberalization: Evidence from Dismantling the License Raj in India. American Economic Review 2008, 98:4, 1397-1412 http://www.aeaweb.org/articles.php?doi=10.1257/aer.98.4.1397 
Arun Mukhopadhyay dan Sal AmirKhalkhali. 2010.Profitability Performance And Firm Size-Growth Relationship, Journal of Business and Economic Research Vol 8 No 9 (2010).DOI https://doi.org/10.19030/jber.v8i9.764

Bilych, Gennady. 2012. Profit and Economic Growth.

Brush, Thomas H, Philip Bromiley, dan Margaretha Hendrickx. 2013. The Free Cash flow Hypothesis for Sales Growth and Firm Performance.

Coad, A. (2009): The Growth of Firms: A Survey of Theories and Empirical Evidence. Edward Elgar: Cheltenham, UK.

Coad, Alex dan Werner Holzi. 2010. Firm Growth: Empirical Analysis. Papers on Economics \& Evolution (http://papers.econ.mpg.de/evo/discussionpapers/2010-02.pdf

Dahl, Drew. 2012. Coincident Correlations of Growth Factors Presented in The Literature of The Field.

Dreyer, Johann; Erasmus, Pierre; Morrison, John; Hamman, Willie. 2013. Sustainable Company Growth as Measured by Cash Flow. Management Dynamics vol.22, no.2, 2013.

Evans, David 1987. The Relationship between Firm Growth, Size, and Age: Estimates for 100 Manufacturing Industries, Journal of Industrial Economics, 1987, vol. 35, issue 4, 567-81

Filho, Nelson H. Barbosa. 2001. International Liquidity and Growth in Brazil. http://www.economicpolicyresearch.org/scepa/publications/workingpapers/2001/cepa200104.pdf

Francis, Bill, Iftekhar Hasan, dan Zenu Sharma. 2011. Leverage and Growth: Effect of Stock Options. https://helda.helsinki.fi/bof/bitstream/handle/123456789/7657/169463.pdf?sequence=1

Geroski, P. and Mazzucato, M. (2002), "Modelling the Dynamics of Industry Populations", International Journal of Industrial Organization, Volume 19, pp. 1003-1022.

Gibrat R. (1931) "Les Inégalités économiques", Paris, France, 1931.

Heikal, Mohd. dan Muammar Khaddafi. 2014. Influence Analysis of Return on Assets (ROA), Return on Equity (ROE), Net Profit Margin (NPM), Debt to equity ratio (DER), and Current ratio (CR), Against Corporate Profit Growth in Automotive in Indonesia Stock Exchange.

Oliveira, Blandina dan Adelino Fortunato. 2005. Firm Growth and Liquidity Constraints: A Dynamic Analysis.

Miguel, Angel Galindo Martin dan Maria Teresa Mendez Picazo. 2002. Cash flow Effects on Economic Growth.

Pasaribu, Rowland Bismark Fernando. 2008. The Influence of Corporate Fundamental to Stock Price in Indonesian Public Companies.

Pradhan, Rudra P. \& Alvin, Mak B. \& Ghoshray, dan Atanu. 2015. The Dynamics of Economic Growth, Oil Prices, Stock Market Depth, and Other Macroeconomic Variables: Evidence from the G-20 Countries.

Rusmin, Emita W. Astami, dan Bambang Hartadi. 2014. The Impact of Surplus Free Cash flow and Audit Quality on Earnings Managemet: The Case of Growth Triangle Countries.

Schleicher, Thomas \& Tahoun, Ahmed \& Walker, Martin. 2010. IFRS Adoption in Europe and InvestmentCash Flow Sensitivity: Outsider Versus Insider Economies.

Schimke, dan Thomas Brenner. 2011. Long-run Factors of Firm Growth - a Study of German Firms.

Segarra, Agusti dan Mercedes Teruel. 2009. Small Firms, Growth, and Financial Constraints.

Storey, D.J., 1994. Understanding the Small Business Sector. 1st Edn., Routledge, London, ISBN-10: 0415100380, pp: 355. 